tinal content). The serotypes isolated from these parts of the intestine are usually recognized as enteropathogenic (oIOI, 086, 08, 02r, etc.).

In healthy animals, the strict anaerobic and the microaerophilic microflora estimated under $\mathrm{CO}_{2}$ according to HUNGATE's method, is dominant. After four days of life, the bacterial content of the abomasum is at least $10^{7}$ bact./g. The colonization of the duodenum and jejunum is variable $\left(\mathrm{IO}^{4}\right.$ to $1 \mathrm{IO}^{9} / \mathrm{g}$ ). In the caecum, colon and faeces, there is less variation (10 $\mathrm{Io}^{8} \mathrm{IO}^{10} \mathrm{bact} / \mathrm{g}$ after the fourth day).

The aerobic and facultative anaerobic microflora represents abouts ro p. Ioo of total microflora and is distributed along the alimentary tract in a manner approximately similar to that of the strict anaerobic microflora.

The genus Lactobacillus constitutes an important part of the digestive microflora of the calf. Lactobacilli colonize progressively the abomasum (10 $3 / \mathrm{g}$ by the $33^{\text {rd }}$ day, $10^{7} / \mathrm{g}$ by the 7 th day) and the ileum (10 $10^{4}-10^{5} / g$ by the 3 rd day, $10^{7} / \mathrm{g}$ from the 8 th day onwards). In the caecum and faeces, lactobacilli rise to $10^{6}-10^{8} / g$ from the 3 rd day onwards.

The genus Streptococcus is rare in the abomasum, duodenum and jejunum. The bacterial contents of the ileum, caecum and faeces are respectively $10^{4}-10^{6}, 10^{4}-10^{8}, \mathrm{IO}^{4}-\mathrm{IO}^{8}$ at about the $3^{\mathrm{rd}}$ day.

W. Perfringens is irregularly present but may be in high numbers (many as high as $10^{8} / \mathrm{g}$ ) and is found only in caecum and colon.

A presomptive identification, based on 50 strains of the dominant microflora, isolated from intestinal contents of four calves, five to seven days old, allowed us to class these strains in the genus Lactobacillus, Bifidobactorium Clostridium, Fusobacterium, Bacteroides, Eubacterium.

These preliminary studies do not yet allow us to draw conclusions on the respective roles of different bacterial species and their relative importance.

This ambitious objective will be difficult to reach if we admit, like J. M. B. RoY and S. H. TERNoutr (Proc. Nutr. Soc. 1972), that the equilibrium of the digestive microflora depends on microbial (surroundings), nutritional (nutrients, digestive enzymes), immunological (immunoglobulins of colostrum and gut), genetic (physiological characteristics of the digestive tract), and even psychophysiological factors (stress).

However, the use of young germ-free ruminants would allow us to study analytically the influence of these different factors.

\title{
OBSERVATIONS SUR LA DYNAMIQUE DES POPULATIONS DE « POLYPLASTRON MULTIVESICULATUM " ET « D'ENTODINIUM » SP (CILIÉS OLIGOTHICHES) DANS LE RUMEN DU MOUTON
}

\author{
J. P. JOUANY, J. SENAUD, P. GRAIN et P. DE PUYTORAC \\ Station de Recherches sur l'Élevage des Ruminants, \\ Centre de Recherches de Clermont Ferrand, I. N. R. A., \\ Theix 63110 Beaumont
}

Dans le cadre des travaux que nous effectuons sur le rôle des corps microbiens du rumen dans la digestion des aliments, nous avons abordé l'étude du développement in vivo de deux espèces de ciliés introduites en quantités connues dans le rumen d'agneaux n'ayant jamais contenu de protozoaires. 
Pour cela, selon la méthode de Williams et Dinusson (1972), nous avons séparé, dès leur naissance, les agneaux de leur mère, qui ont été élevés dans des conditions empêchant toute contamination ultérieure. Six agneaux ont été nourris au lait jusqu'à l'âge de 7 semaines, ils ont reçu ensuite un foin de graminées et un aliment concentré jusqu'à l'âge de I4 semaines, puis seulement du foin, distribué deux fois par jour $(8 \mathrm{~h} 30$ et $\mathrm{I} 6 \mathrm{~h}$ 3o) et laissé pendant deux heures à leur disposition.

Par une canule du rumen (placée à l'âge de i I semaines) de 4 animaux, nous avons introduit de 800 à goo Polyplastron multivesiculatum et ı à 20 Entodinium sp., triés, comptés et lavés sous une loupe binoculaire dans du liquide de Hungate et provenant d'un rumen de mouton recevant le même foin de graminées que les moutons sans ciliés. Pour chacune des deux espèces d'Infusoires ensemencées, nous avons effectué des comptages de ciliés toutes les trois heures pendant 15 jours dès que leur concentration a été de 30 cellules par millilitre de liquide de rumen.

I. Quels que soient l'espèce considérée et l'animal étudié, la population d'Infusoires a atteint un état d'équilibre 5 jours environ après l'apparition des ciliés (3० par $\mathrm{ml}$ ) dans le liquide du rumen. La valeur du "plateau " est à peu près la même chez les 4 moutons, dans les conditions d'alimentation ci-dessous précisées. Elle est de $\mathrm{I} \times 1 \mathrm{1}^{4} \mathrm{par} \mathrm{ml}$ pour Polyplastron et $\mathrm{I} 8 \times \mathrm{ro}^{4}$ par $\mathrm{ml}$ pour Entodinium (fig. r).

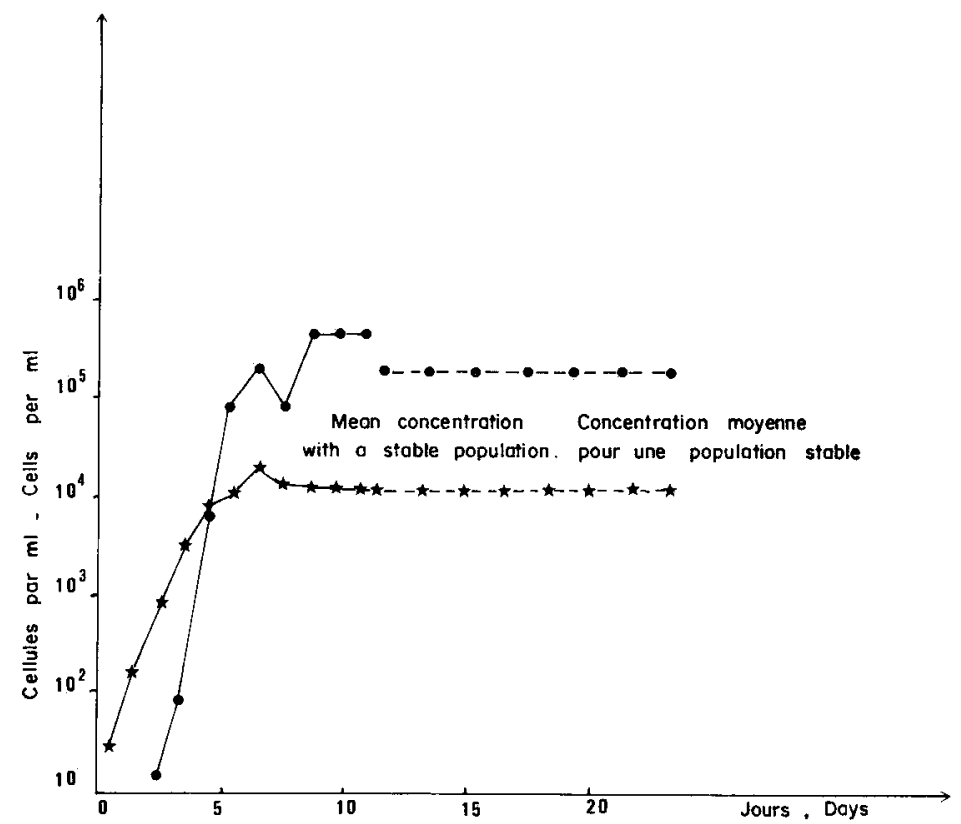

FIG. I. - Mise en place de deux populations de ciliés dans un rumen de mouton

Fig. 1. - Establishment of two populations of ciliates in a sheep rumen

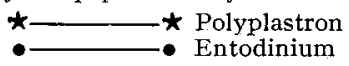

2. Le calcul des taux d'accroissement respectifs des deux populations Polyplastron, Entodinium leur permettant à partir d'un effectif de 30 cellules par ml, d'atteindre leur effectif maximum ( $\mathrm{I} \times \mathrm{IO}^{4}$ d'une part; $18 \times$ IO $^{4}$ d'autre part), montre que la population d'Entodinium s'accroit à peu près une fois et demie plus vite que celle de Polyplastron. La vitesse d'établissement de la population d'Entodinium a été de 2,5 tandis que pour Polyplastron, elle a été de I,7 par $24 \mathrm{~h}$.

3. Les variations de la teneur du rumen en Polyplastron, dont la population est en état d'équilibre, ont été suivies pendant $4^{8} \mathrm{~h}$, après une correction des comptages effectués toutes les 
deux heures. Cette correction qui tient compte des variations du volume du rumen au cours de la journée, a été effectuée par la mesure de la concentration de PEG infusé en continu dans le rumen d'un animal témoin. Nous avons observé régulièrement une chute de la concentration des ciliés 2 à $4 \mathrm{~h}$ après le début du repas qui est due vraisemblablement à leur dilution dans une quantité plus importante d'aliments présents dans le rumen ainsi qu'à une vidange simultanée du c ontenu de rumen vers le feuillet. Puis la concentration de ciliés s'accroît pendant environ $4 \mathrm{~h}$ car le nombre de cellules en division atteint alors sa valeur maximale. Inversement, c'est io $\mathrm{h}$ après le repas du soir que la concentration est à nouveau la plus basse, voisine de celle observée $2 \mathrm{~h}$ après le début des repas (fig. 2). Nous avons donc noté trois périodes pendant lesquelles le nombre de cellules en division est maximum qui correspondent aux trois phases de croissance mises en évidence en $24 \mathrm{~h}$ (fig. 2 ).

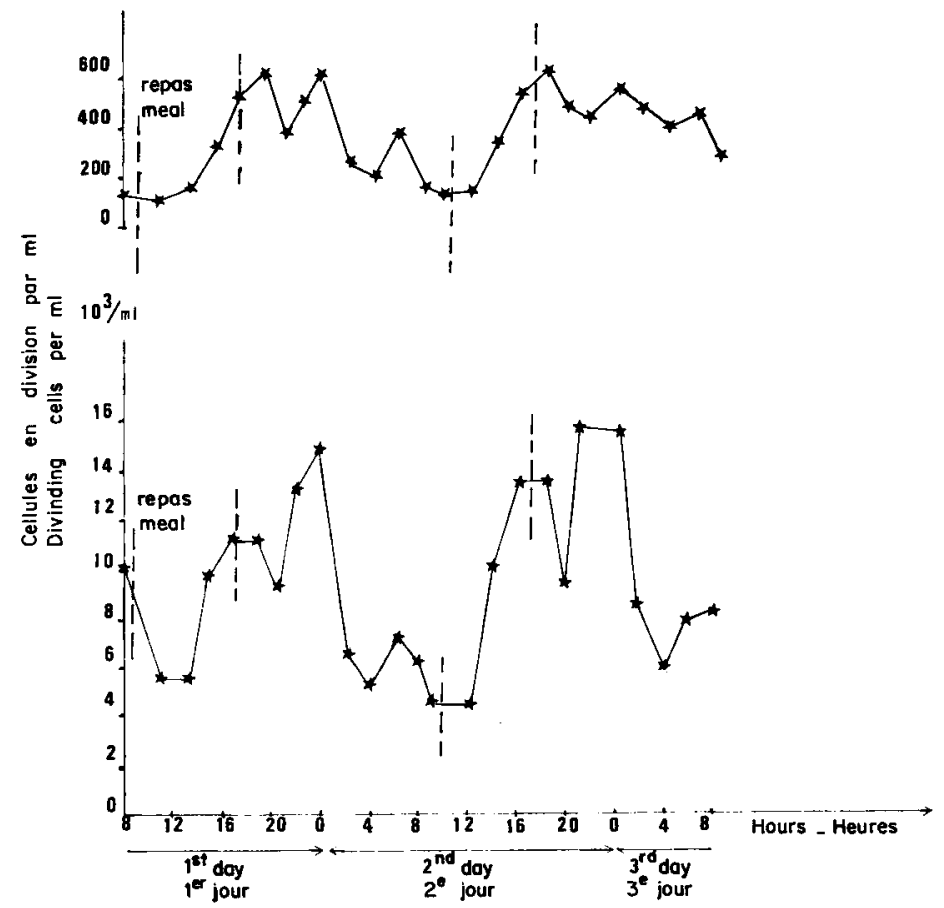

FIG. 2. - Variations nycthémérales de la concentration en Polyplastron dans le rumen

FIG. 2. - Diurnal variations of the Polyplastron concentration in the rumen

4. Le débit moyen de vidange du rumen ayant pu être calculé par l'infusion de PEG en continu, si l'on admet qu'il y a même concentration de ciliés dans le liquide du rumen évacué vers le feuillet que dans celui qui demeure dans la panse, nous avons pu estimer que le nombre de ciliés qui passent en $24 \mathrm{~h}$ dans le feuillet est 3,4 fois plus élevé que le nombre de ciliés présents. dans le rumen.

5. Sur cette base, nous avons pu calculer les vitesses journalières de la multiplication de Polyplastron. La concentration de départ étant fixée à 30 cellules par $\mathrm{ml}$, nous avons montré, que pendant la phase logarithmique de croissance, une cellule se divise en moyenne 4,30 fois le $\mathrm{I}^{\mathrm{er}}$ jour ; 4,03 le $2^{\mathrm{e}}$ jour ; 3,83 fois le $3^{\mathrm{e}}$ jour, 2,86 fois le $4^{\mathrm{e}}$ jour et $\mathrm{I}, 96$ fois le $5^{\mathrm{e}}$ jour. La vitesse moyenne de multiplication pendant la phase d'équilibre est de $I, 7$.

Tous ces résultats sont discutés en fonction des faits jusqu'alors connus d'après des estimations globales in vivo ou des données obtenues dans des cultures in vitro. 


\section{SUMMARY}

\section{OBSERVATIONS ON THE DYNAMICS POPULATIONS OF POLYPLASTRON MULTIVESICULATUM}

AND ENTODINIUM SP (CILIARY OLIGOTRICHIA) POPULATIONS IN THE SHEEP RUMEN

Within our experimental program concerning the role of bacterial populations of the rumen in the digestion of feeds, we realized a study in vivo of two ciliated species introduced, in known quantities, into the lamb rumen which had never contained any protozoa.

According to the method of WiLliams and Dinusson (1972) the lambs were separated from their dams at birth and kept in conditions so as to avoid any further contamination. Six lambs were fed on milk till the age of 7 weeks and then with grass-hay and concentrate food up to 14 weeks of age. From that moment, they received only hay, offered twice a day $(8.30 \mathrm{a} . \mathrm{m}$. and 4.30 p. m.) and left at their disposal for 2 hours.

Through a rumen cannula, placed at the age of II weeks in 4 animals, we introduced ro-2o Entodinium sp., sorted out, counted and washed under a binocular magnifier in Hungate liquid and proceeding from a rumen of sheep which had received the same grass-hay as the sheep without ciliated populations. For each of the inoculated species of infusoria, countings of the ciliated species were made every 3 hours per 15 days from the moment when their concentration represented 30 cells per milliliter rumen juice.

I. Whatever the species considered and animal studied, the population of infusoria reached a stage of balance about 5 days after appearance of the ciliated species $(30 \mathrm{ml})$ in the rumen juice. The "plateau " value was almost similar in the 4 sheep under the below indicated feeding conditions. This value was $\mathrm{I} \times 1 \mathrm{I}^{4}$ per $\mathrm{ml}$ for Polyplastron and $\mathrm{I} 8 \times 10^{4}$ per $\mathrm{ml}$ for Entodinium (fig. I).

2. Calculation of the respective growth rates of the two populations (Polyplastron, Entodinium, i.e. starting with 30 cells per $\mathrm{ml}$ and reaching a maximum population of $\mathrm{I} \times 10^{4}$ and $18 \times 10^{4}$ respectively) shows that Entodinium grows about $\mathrm{I}$ I/2 times faster than Polyplastron. The rate of establishment of the Entodinium population was 2.5 whereas that of the Polyplastron population was $\mathrm{I} .7$ per $24 \mathrm{~h}$.

3. The variations of the rumen content of Polyplastron (population in a stage of balance) were followed for $4^{8} \mathrm{~h}$ after correction of the countings made every 2 hours. This correction, which takes into account the variations in the volume of the rumen in the course of the day, was made by measuring continuously the PEG concentration in the rumen of a control animal. A fall in the concentration of ciliated bodies was regularly noted 2 to $4 \mathrm{~h}$ after the beginning of the meal. This was probably due to the fact that they were diluted in a larger amount of food present in the rumen as well as to a simultaneous emptying of the rumen content towards the omasum. Thereafter the concentration of ciliated bodies increased for about $4 \mathrm{~h}$, at the moment when the number of dividing cells reached its maximum value. Conversely, to $\mathrm{h}$ after the evening meal the concentration was again the lowest and showed a value similar to that observed $2 \mathrm{~h}$ after the beginning of the meal (fig. 2). Thus, three periods were observed during which the number of dividing cells was maximum, periods that corresponded to the three growth phases evidenced within $24 \mathrm{~h}$ (fig. 2).

4. The mean emptying rate of the rumen having been calculated by continuous infusion of PEG and supposing that the concentration of ciliated bodies in the rumen juice emptied towards the omasum is the same as that remaining in the rumen, it was possible to estimate that the number of ciliated bodies passing in the Omasum within $2.4 \mathrm{~h}$ is 3.4 times higher than that present in the rumen. 
5. On this basis, we were able to calculate the daily growth rate of Polyplastron. The initial concentration having been fixed to $3^{\circ}$ cells $/ \mathrm{ml}$, we showed that during the logarithmic growth phase, a cell is divided on an average 4.30 times the first day; 4.03 the second day, 3.83 the third day, 2.86 times the fourth day and 1.96 times the fifth day. During the equilibrium phase the mean rate of multiplication is $\mathrm{r} .7$.

All these results are discussed according to the facts until then known from in vivo general estimates or from obtained data in in vitro cultures.

\title{
ACTION DE LA FLORE MicRobIENNE DU TRACTUS DIGESTIF SUR LE MÉTABOLISME DES SELS BILIAIRES. DÉGRADATION DE L'ACIDE $\beta$-MURICHOLIQUE
}

\author{
E. SACQUET, Y. VAN HEIJENOORT, M. RIOTTOT et P. RAIBAUD \\ Groupe des Laboratoires de Gif sur Yvette, C. N. R. S., \\ 91- Gif sur Yvette
}

La comparaison entre rat axénique et rat holoxénique permet d'apprécier dans toute son ampleur l'action que la flore microbienne du tractus digestif exerce sur le métabolisme des sels biliaires.

Chez le rat axénique mâle la quantité totale des sels biliaires présents au niveau de l'intestin grêle est plus que doublée et les proportions respectives des acides cholique et $\beta$-muricholique sont très différentes : chez le rat axénique l'acide cholique constitue $35 \mathrm{p}$. Ioo des acides biliaires totaux présents au niveau de l'intestin grêle et l'acide $\beta$-muricholique $54 \mathrm{p}$. 10o, alors que chez le rat holoxénique les proportions sont de $6 \mathrm{I} \mathrm{p}$. Ioo pour l'acide cholique et $12 \mathrm{p}$. Ioo pour l'acide $\beta$-muricholique.

L'établissement dans le tractus digestif du rat axénique de souches bactériennes qui ne métabolisent pas les sels biliaires mais qui réduisent le cæcum, détermine une diminution de la quantité des sels biliaires qui retrouve ainsi la valeur qu'elle possède chez le rat holoxénique, mais ne modifie en rien la composition des sels biliaires qui demeure ce qu'elle est chez le rat axénique. Il n'y a donc pas de liaison entre ces deux caractères.

De très nombreuses hypothèses se présentent concernant le mécanisme par lequel la flore microbienne diminue la proportion d'acide $\beta$-muricholique. L'une d'elles est que cette diminution provient d'un catabolisme particulièrement actif de cette espèce chimique par certaines bactéries intestinales. Il est utile pour entreprendre cette étude de connaitre les métabolites bactériens que le flore microbienne forme chez le rat holoxénique. Dans ce but, de l'acide $\beta$-muricholique- $4^{-14} \mathrm{C}$ a été administré à deux rats holoxéniques ; les matières fécales excrétées dans les jours qui suivent ont été traitées selon la méthode de Grundy et Ahrens; les esters méthyliques des acides biliaires ont été chromatographiés sur couche mince de gel de silice et la répartition de la radioactivité sur ces chromatogrammes a été déterminée par dosage en scintillation liquide après élution.

Cette expérience montre que l'acide $\beta$-muricholique est rapidement catabolisé puisque 3 jours après l'administration orale il a complètement disparu chez l'un des rats et ne représente plus que 2,5 p. Ioo de la radioactivité excrétée ce jour-là chez l'autre rat. Cette disparition s'accompagne de la formation d'au moins ro composés marqués qui sont observés sur les chromatogrammes. La radioactivité la plus importante apparaît au niveau de l'ester méthylique de l'acide hyodésoxycholique : sur les chromatogrammes obtenus à partir des fèces recueillies le $3^{\mathbf{e}}$ jour, $62 \mathrm{p}$. roo

Annales de Biologie animale. - I973. 